\title{
Physico-Chemical Characterization of an Urban Wastewater Effluent and its Impact on the Receiving Environment: Oued Nfifikh (Morocco)
}

\author{
Chaimaa Merbouh ${ }^{1 *}$, Soukaina Namoussi', Mohamed Kabriti ${ }^{1,2}$, \\ Ayoub Naamane', Abdeslam Rihane ${ }^{3}$, Nadia lounes ${ }^{1}$ \\ 1 Laboratory of Ecology and Environment, Faculty of Sciences Ben M'Sik, Hassan II University of Casablanca, \\ Cdt Driss El Harti Av., P.B. 7955 Sidi Othmane, Casablanca, Morocco \\ 2 National Laboratory for Pollution Research and Monitoring (LNESP), Ministry of Energy, Mines and Environment, \\ Department of Environment, Mohamed Ben Abdellah Erregragui Av. Madinat Al-Irfane, Rabat, Morocco \\ ${ }^{3}$ Department of Life and Earth Sciences, Regional Center for Education and Training Trades (CRMEF) of \\ Casablanca-Settat, P.B. 20340 Stendhal Av., Casablanca, Morocco \\ * Corresponding author's e-mail: chaimaa.mrbh@gmail.com
}

\begin{abstract}
Oued Nfifikh is among the least studied Moroccan rivers. Thus, the primary aim of this study was to shed light on the quality of this undervalued stream. Its downstream part is affected by one of the most crucial environmental issues. It receives the discharges of wastewater evacuated precariously without prior treatment, which might lead to the degradation of the overall ecological status of this fluvial hydrosystem. This research work aimed to study the physicochemical water quality downstream the river Nffikh through a monthly monitoring of the physicochemical parameters' indicator of pollution, from August 2018 to July 2019. The results obtained show that the stream is exposed to high pollution which is mainly organic. Consequently, the wastewater represents a major cause of water quality degradation of this receiving environment: ecological and health impacts are therefore to be expected.
\end{abstract}

Keywords: Oued Nffikh, waterstream, wastewater, physicochemical quality, pollution.

\section{INTRODUCTION}

The sustainability of sufficient water resources has become one of the major concerns of our century. In fact, it represents an obstacle towards the satisfaction of the growing population's needs in a global context marked by climate change and its hydrological consequences. This problem is not limited to the amount of water resources, it also impacts their quality. For instance, continental aquatic ecosystems are under an increasing stress from a wide array of anthropogenic impacts, which are direct results of the socio-economic growth and climate change. The degradation of the overall ecological status of hydrosystems and the deterioration of their water quality are the main consequences, thereby compromising the various uses of water.

At the national level, numerous studies have reported the various effects of the industrial and urban discharges on the quality of water resources as well as the impact of the pollution on the continental aquatic ecosystems. Amongst those studies, the work of Bzioui published in 2004 and the reports submitted in 2009 and 2014(a) by (MDCEau) on water resources in Morocco can be highlighted.

Various Oueds and river basins have been the subject of specific water quality studies. Several examples can be stated, such as the case of Oued El Maleh, which has been studied by Oubraim in 2002. Then, Oued Moulouya under the study of Makhoukh et al. in 2011, and Oued Hassar's issues were tackled by Fouad et al. in 2014 and by Nahli et al. in 2015.

Moreover, Oued Merzeg has been assessed by Mounjid et al. in 2014, and the Sebou basin by Hayzoun in 2014 as well. The Beht watershed was evaluated by Lakhili et al. in 2015 and finally 
Oued Daliya, a tributary of Oued Nfifikh was inspected by Iounes et al. in 2016.

If several streams attracted much interest among the community of scientists as shown previously, no specific study regarding the water quality of Oued Nffikh had been published according to the available documentation up to date, except the work of Tazi et al. in 2004, which focused on the impact of climate on the estuarian of Oued Nfifikh. This Oued was only briefly mentioned in some environmental impact assessment or water quality reports. For instance, the study published in 2015 by the Hydraulic Basin Agency of Bouregreg and Chaouia (ABHBC) is only giving it as one example amongst many water streams present in the Chaouia watershed-coastal areas, in order to support their point regarding the existence of pollution sources contributing on the degradation of water quality.

Thus, this work is part of a pioneering study of Oued Nffifk water quality, a stream that has a major socio-economic importance for the inhabitants of its basin (irrigation, livestock watering, potable water, industry ...). The current study is focused on its downstream part which is affected by different sources of pollution. It receives liquid effluents, which are discharged in a precarious manner and without prior treatment, from some of the riparian agglomerations of BenYakhlef (Louisia) municipality.

\section{STUDY AREA DESCRIPTION}

Due to the maritime influences, the study area is part of the semi-arid bioclimatic belt, where the summers are dry and hot and the winters are mild and humid (Communal monography, 2010; General monography, 2015). Moreover, the area records an average annual rainfall of around 400 $\mathrm{mm}$ and a temperature varying between $7^{\circ} \mathrm{C}$ and $27^{\circ} \mathrm{C}$. Peaks can reach up to $40^{\circ} \mathrm{C}$ during the year, but their frequency remains exceptional (Akil, 1990; General monography, 2015).

The rocky outcrops in the study area are usually made up of schists and red pelites with basaltic doleritic intercalations (Farki et al., 2012; Farki et al., 2014; Farki et al., 2016).

Elongated in its general shape, Oued Nfifikh extends over an area of about $607 \mathrm{~km}^{2}$. The river takes its source in the region of Ziaida at Benslimane and pours into the Atlantic Ocean at the city of Mohammedia. The stream is not controlled by any upstream dam and the flow characteristics of

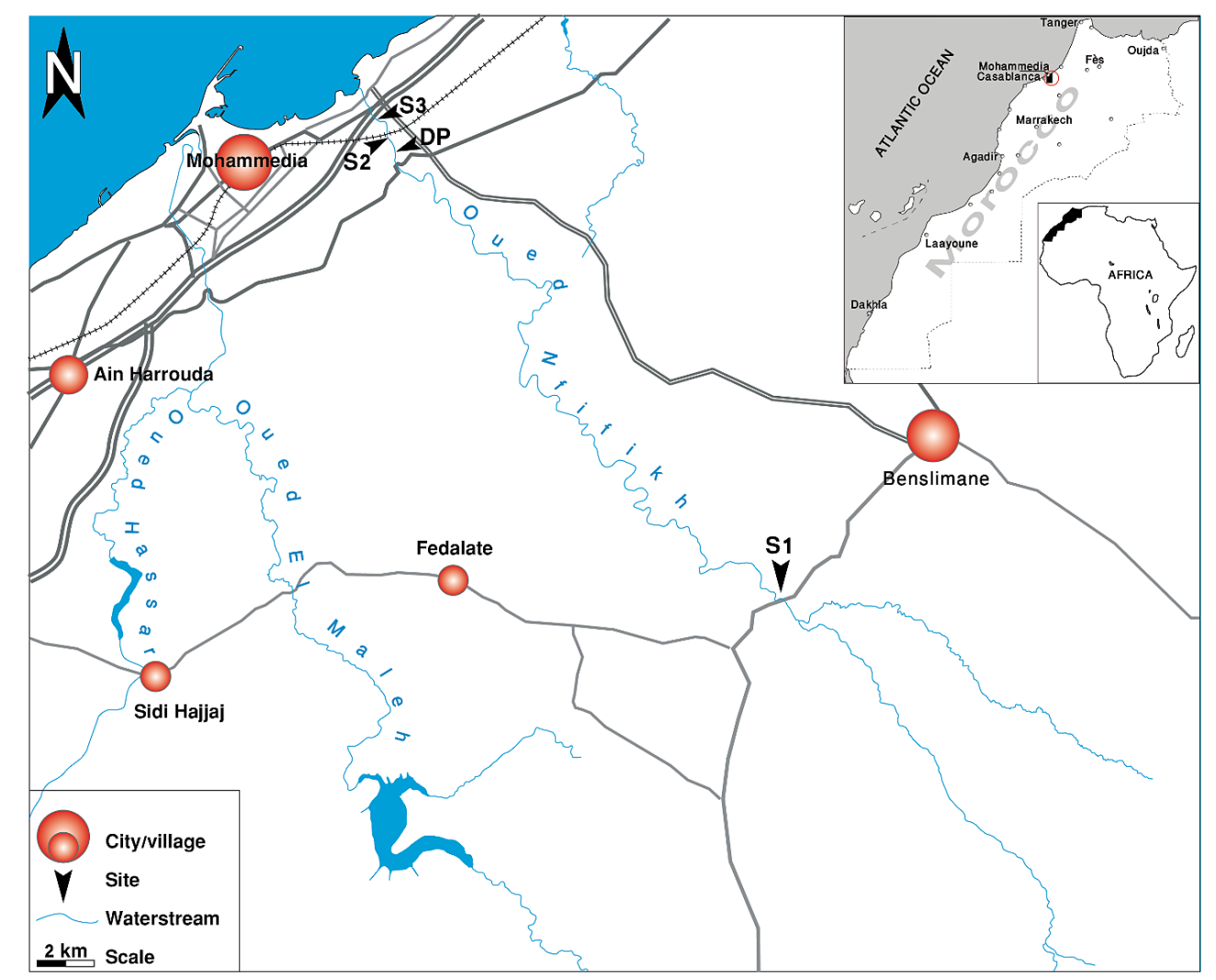

Figure 1. Location map of sampling sites in Oued Nfifikh $\left(\mathrm{S}_{1}\right.$ : reference site, DP: Discharge Point, $\mathrm{S}_{2}$ and $\mathrm{S}_{3}$ : sites downstream DP) 
this basin are evaluated at the Feddane Taba hydrometric station at $180 \mathrm{~m}^{3} / \mathrm{s}$ for a 10 -year return period. However, Oued Nfifikh is generally dry during the low flow period (ABHBC, 2011).

\section{LOCATION OF SAMPLING SITES}

Concerning this study, which covers a period of twelve months starting from August 2018 until July 2019, four sites along of the river were targeted in order to evaluate the physico-chemical quality of their water. It consists of an outfall, through which the wastewater runs located within the geographical coordinates $\left(33^{\circ} 42^{\prime} 0,75^{\prime}\right.$ ' $\mathrm{N}, 7^{\circ} 19^{\prime} 42,64^{\prime} \mathrm{W}$ ), along with three different sample withdrawals. Two amongst them are situated downstream the discharge point within the coordinates $\left(33^{\circ} 42^{\prime} 15,78^{\prime \prime} \mathrm{N}, 7^{\circ} 19^{\prime} 52,97^{\prime}\right.$ 'W) and $\left(33^{\circ} 42^{\prime} 40,80^{\prime \prime} \mathrm{N}, 7^{\circ} 20^{\prime} 11,27^{\prime \prime} \mathrm{W}\right)$, while the remaining one, a reference site, is located on the upstream within the coordinates $\left(33^{\circ} 33^{\prime} 44,00^{\prime \prime}\right.$ N, 7¹1'12,20” W) (Fig. 1).

\section{MATERIALS AND METHODS}

The sampling of surface water was carried out between 9 a.m. and 12 p.m. following the methodology dictated by NF EN ISO 5667-1 [21] using polyethylene bottles, and all the testing equipment used for the in-situ measurements were calibrated in advance according to the manufacturer's instruction. Temperature, $\mathrm{pH}$, electrical conductivity and dissolved oxygen were measured using a portable multi-parameter ( $\mathrm{pHenom-}$ enal MU $6100 \mathrm{H}$ ), while turbidity was measured using a handheld infrared turbidity meter (Eutech $T N-100)$. The samples were then stored at $4^{\circ} \mathrm{C}$ in the dark during transport to the laboratory and analyzed within the same standard cited above.

The analyses of TSS, $\mathrm{BOD}_{5}$, COD, nitrogenous compounds and phosphorus compounds were performed according to the methods recommended by the AFNOR standards (Table 1).

All these elements make it possible to evaluate the degree of pollution of Oued Nfifikh water and to assess its self-purification capacity.

\section{RESULTS AND DISCUSSION}

\section{Temperature}

In general, the recorded temperature values correspond to a seasonal variation. The lowest value $\left(7.5^{\circ} \mathrm{C}\right)$ is recorded during the wet season and the highest $\left(31.2^{\circ} \mathrm{C}\right)$ is observed during the dry season (Fig. 2). This variation demonstrates

Table 1. Parameters and analysis methods

\begin{tabular}{|l|l|c|}
\hline \multicolumn{2}{|c|}{ Parameter } & \multicolumn{2}{c|}{ Analysis methods } & NF T 90-105-2 \\
\hline TSS & $\begin{array}{l}\text { Filtration on } 1,5 \mu \mathrm{m} \text { porosity glass fiber filter membrane } \\
\left(\text { Whatman GFC) dries at } 105^{\circ} \mathrm{C}\right.\end{array}$ & NF T 90-101-2001 \\
\hline COD & Open reflux method & NF EN 1899-1998 \\
\hline BOD $_{5}$ & Manometric method using Oxitop Velp Scientifica manometer & NF T 90-015-1-1996 \\
\hline Ammonium ion & Indophenol-blue method & NF EN 1189-1996 \\
\hline Total phosphorus & Peroxodisulfate oxydation method & \\
\hline
\end{tabular}



Figure 2. Spatio-temporal variation in water temperature (left) and in air temperature (right) 
the relationship between the temperature of water and air. The heat exchange between the two matrices establishes this relationship. This exchange is also strongly favored by the shallow depth of the water at the sampling sites.

The average temperature of surface water at $\left(\mathrm{S}_{1}\right)$ is $19.4^{\circ} \mathrm{C}$ and at $\left(\mathrm{S}_{2}\right.$ and $\left.\mathrm{S}_{3}\right)$ is $20.4^{\circ} \mathrm{C}$. As for the waters of the discharge point (DP), the average temperature is $19.9^{\circ} \mathrm{C}$.

In order to assess the overall quality of Oued Nffik $h$ waters, the results obtained were compared to the Moroccan standards in the field of water. Thus, on the spatial scale ranging from $\left(\mathrm{S}_{1}\right)$ to $\left(\mathrm{S}_{2}\right.$ and $\mathrm{S}_{3}$ ) and according to the surface water quality grid, the water from those sites is qualified as good to excellent quality (SEEE, 2007). Regarding the wastewater (DP), the recorded results do not exceed the discharge limit value applicable to direct discharges into surface water (MDCEau, 2014 b).

\section{pH (hydrogen potential)}

The $\mathrm{pH}$ values obtained for all the sites during the study period vary between 7.5 and 8.3 (Fig. 3). On the basis of these results, the waters studied are slightly neutral to basic. Overall, the average $\mathrm{pH}$ values vary between 7.7 and 7.8 and the average differences in hydrogen potential between the dry season and the wet season are generally low. This shows the absence of any seasonal action on the $\mathrm{pH}$, it varies independently of the seasons.

The $\mathrm{pH}$ values of the water from the sites $\mathrm{S}_{1}$, $\mathrm{S}_{2}$ and $\mathrm{S}_{3}$ are in concordance with the Moroccan standards which qualify these waters as of excellent quality (SEEE, 2007). According to the Moroccan standards, the general limit values for discharge into surface water vary between 5.59.5 , and the average value of this parameter for

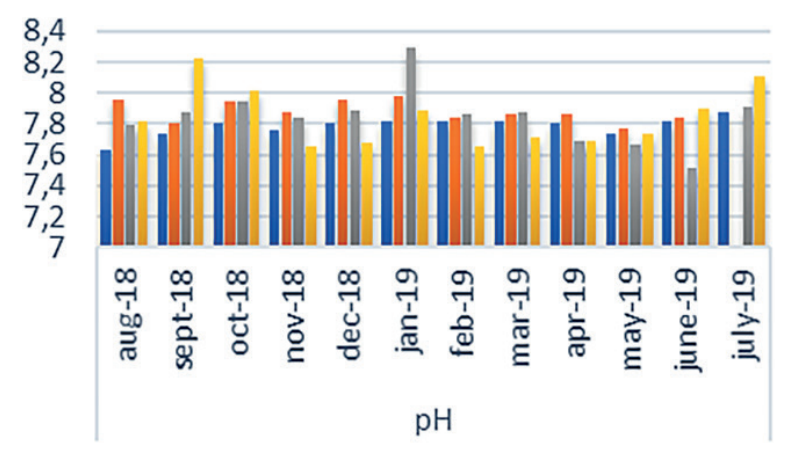

$\square \mathrm{S} 1 \square \mathrm{DP} \square \mathrm{S} 2 \square \mathrm{S} 3$

Figure 3. Spatio-temporal variation of hydrogen potential $(\mathrm{pH})$ wastewater from site (DP) is 7.8. Therefore, these waters have no impact on water quality downstream from Oued Nfifikh.

\section{Electrical conductivity}

The values of the electrical conductivity (EC) varied between $1.46 \mathrm{mS} / \mathrm{cm}$ and $4.84 \mathrm{mS} / \mathrm{cm}$. Overall, the average conductivity values vary between $3.01 \mathrm{mS} / \mathrm{cm}$ and $4.06 \mathrm{mS} / \mathrm{cm}$ for surface water $\left(\mathrm{S}_{1}, \mathrm{~S}_{2}\right.$ and $\left.\mathrm{S}_{3}\right)$ and an average value of $2.64 \mathrm{mS} /$ $\mathrm{cm}$ for wastewater from the discharge point (DP).

The results obtained provide the information on the increase in water conductivity in the dry and wet season; this increase is much greater during the rainy period. The high values observed at the sites $\left(\mathrm{S}_{1}, \mathrm{~S}_{2}\right.$ and $\left.\mathrm{S}_{3}\right)$ are most likely related to the Triassic outcrops crossed by the water along Oued Nfifikh. Gartet et al. (2001) and Nahli et al. (2015) found high conductivity values in Oued Lebéne and Oued Hassar, respectively, which are also related to the Triassic outcrops crossed by the water.

However, similarly to $\mathrm{pH}$, the variations in electrical conductivity are associated with the variations in the dissolved carbon dioxide content, which are linked to the decomposition of organic matter of animal or human origin (Rodier et al., 2009; ADEME, 2013). According to the Francophone network on water and sanitation (Réfea, 2001), the contrasts of the EC make it possible to highlight pollution, and areas of mixing or infiltration. As a matter of fact, the high values of the conductivity obtained translate continuous external inputs of mineral salts along the water stream.

For instance, the influence that the agricultural and livestock activities adopted at the site

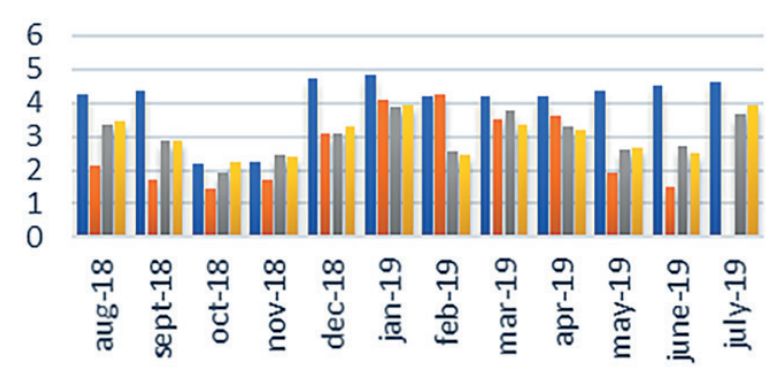

(E.C) $\mathrm{ms} / \mathrm{cm}$

$\square \mathrm{S} 1 \square \mathrm{DP} \square \mathrm{S} 2 \square \mathrm{S} 3$

Figure 4. Spatio-temporal variation of electrical conductivity (E.C) 
$\left(\mathrm{S}_{1}\right)$ might have on the conductivity variations. As to the other evaluated sites $\left(\mathrm{S}_{2}\right.$ and $\left.\mathrm{S}_{3}\right)$, the high conductivity values might be associated to direct discharges of wastewater (grey and black water) and also to domestic waste discharged into the watercourse.

By comparing the results obtained with the Moroccan pollution standards and surface water quality grid, the conductivity values of the water from the sites $\left(\mathrm{S}_{1}, \mathrm{~S}_{2}\right.$ et $\left.\mathrm{S}_{3}\right)$ are within the range of class 5 of the standard (SEEE, 2007). Thus, they are qualified as of very poor quality.

The average value of conductivity for the discharge point water (DP) does not exceed the value proposed by the standard (MDCEau, $2014 \mathrm{~b}$ ). However, higher values exceeding the standard can occasionally be recorded during the winter season which is characterized by significant rainfall inputs and by the releases of masses of highly mineralized wastewater from Ben Yakhlef-Louisia's agglomerations.

\section{Turbidity and TSS}

The average turbidity values are 45.15 NTU; 163.55 NTU; 99.91 NTU and 39.07 NTU for the sites $\mathrm{S}_{1}, \mathrm{~S}_{2}, \mathrm{~S}_{3}$ and $\mathrm{DP}$, respectively.

However, variations in the measurements were observed either temporally, represented by the increase in turbidity values during the rainy period (Fig. 5), or spatially along the watercourse. By interpreting the results spatially, the site $\left(\mathrm{S}_{1}\right)$ represents an average value which according to Rodier et al. (2009) and in the absence of a Moroccan standard, it is within the normal range of turbidity of surface water, while the average values found in sites $\mathrm{S}_{2}$ and $\mathrm{S}_{3}$ are very high from the normal range of turbidity given by Rodier et al. (2009).

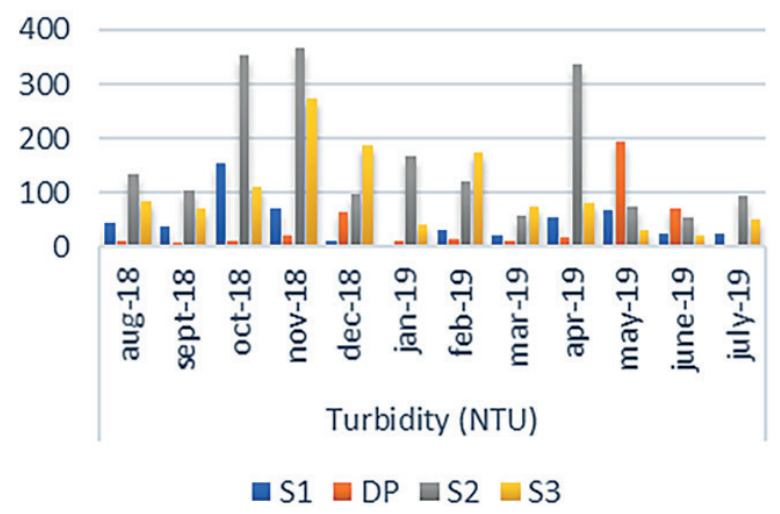

Figure 5. Spatio-temporal variation of turbidity
According to LeChevalier et al. (1981) high measurements or fluctuations in measurements may indicate a water quality problem. In fact, the highest turbidity values are observed at site $\left(\mathrm{S}_{2}\right)$. This site is mainly supplied by raw wastewater from the discharge point. In addition, the highaltitude position of the sewage outfall relative to the site $\left(\mathrm{S}_{2}\right)$, causes the wastewater discharged to arrive in cascade, thus, increasing the turbidity of the water and contributing to the degradation of the environment.

By comparing the turbidity values obtained between all the sites, it was found that itself, the water coming from the discharge point does not have a high turbidity. Its waters are generally gray water from domestic activities and also from the traditional Moroccan Hammam baths installed in the study area (Ben Yakhlef - Louisia). The highest turbidity values of the waters at $\left(\mathrm{S}_{2}\right)$ were only recorded during the rainy period, when combined gray and black water releases were observed.

However, in Morocco, there are no fixed limit values for direct effluent of discharges into the environment or a standard to assess the quality of surface water for turbidity. According to Rodier et al. (2009), above 200 NTU the parameter is no longer relevant. It is then necessary to use the TSS parameter, which in this context is the most faithful parameter to represent and quantify the particulate matter.

The suspended solids content obtained for the water at the studied sites vary between 7 and 414 mg/l (Fig. 6). According to DeVillers et al. (2005) and Rodier et al. (2009), suspended solids depend on the nature of the land crossed, the season, rainfall, water flow regime and the nature of the discharges. Other authors (Makhoukh et al. 2011; N'Diaye et al. 2013 and Reggam et al. 2015) confirm through their work on different rivers that during strong hydrological events, the TSS load tends to increase. This increase is attributed to the phenomenon of intense erosion of the land and the runoff of soil particles, plant and animal debris into the watercourses.

The observed increase of TSS is consistent with the results obtained for turbidity (Fig. 5). In fact, the values of suspended solids obtained in the rainy period are high compared to those in the dry period, except for the site $\left(\mathrm{S}_{2}\right)$ during the December sampling period. The low values of TSS observed during December in the site $\left(\mathrm{S}_{2}\right)$ would be due to the high foam loadings of the effluents 


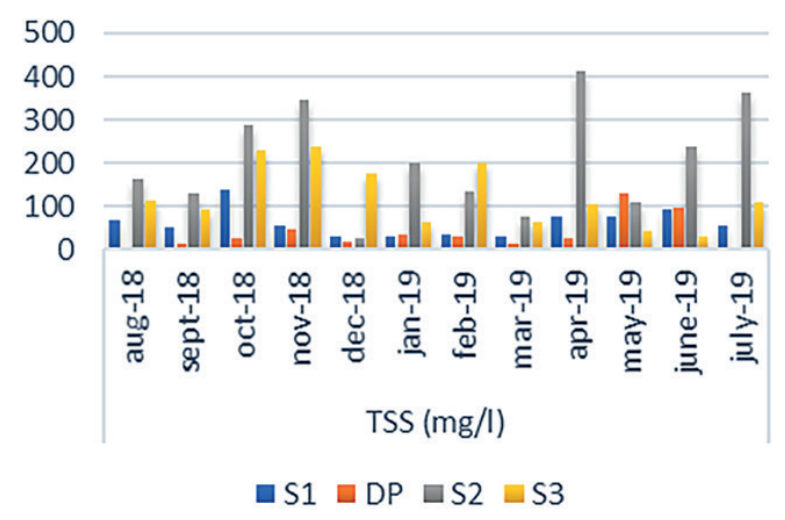

Figure 6. Spatio-temporal variation of TSS

discharged, which sequester the suspended matter and reducing their quantity in the sampled water.

The average values of suspended matter in surface water are $60.41 \mathrm{mg} / 1 ; 206.58 \mathrm{mg} / \mathrm{l}$ and 121.58 $\mathrm{mg} / \mathrm{l}$ respectively for the sites $\left(\mathrm{S}_{1}, \mathrm{~S}_{2}\right.$ and $\left.\mathrm{S}_{3}\right)$, while the average value of TSS at the discharge point is $40.18 \mathrm{mg} / 1$ (Fig. 6). Spatially, the sites $\left(\mathrm{S}_{2}\right.$ and $\mathrm{S}_{3}$ ) downstream of the discharge point record the highest averages. Several studies, e.g. ElHaji et al., (2012); Yapo et al., (2012) and Makhoukh et al., (2011) are in agreement with the obtained results. Therefore, high values of the TSS affect the transparency of water and decrease the penetration of light and, consequently, the photosynthesis. It can also affect the fish's breathing. As well, the suspended matter stored can accumulate high amounts of toxic substances (metals, pesticides, polycyclic aromatic hydrocarbons...) (Hébert and Légaré, 2000; DeVillers et al., 2005).

By comparing the results shown in figure 6 to the Moroccan standards, the waters from the site (DP) are per with wastewater discharge standards set at $150 \mathrm{mg} / 1$ (MDCEau, 2014 b). Paradoxically and according to the Moroccan standard of surface water quality (SEEE, 2007), the waters from the sites $\left(\mathrm{S}_{2}\right.$ and $\left.\mathrm{S}_{3}\right)$ are within the range of class 2 and 3 of the standards, thus qualifying them as medium to good quality, regardless of the very apparent visual degradation of the landscape. As for the waters from the site $\left(\mathrm{S}_{1}\right)$, the standards allow classifying them as of good quality.

\section{COD (Chemical Oxygen Demand) and BOD $_{5}$ (Biological Oxygen Demand)}

For the current study, the values recorded for these two parameters are shown in figures 7 and 8:

According to the results obtained (Fig. 7), the COD values range from $28.8 \mathrm{mg} \mathrm{O}_{2} / 1$ to $672 \mathrm{mg}$
$\mathrm{O}_{2} / 1$. In general, the average value of the chemical oxygen demand in the waters of the site $\left(\mathrm{S}_{1}\right)$ is $69.6 \mathrm{mg} \mathrm{O}_{2} / 1$. The COD peaks observed in December and January, could be the result of the rain runoff causing the leaching of organic and mineral fertilizers, as well as, the transport of animals' and plants' debris from lands adjoining the sampling site $\left(\mathrm{S}_{1}\right)$ towards the watercourse.

The comparison of the COD values obtained during this study with the Moroccan surface water quality grid (SEEE, 2007), reveals that the assessed waters from site $\left(\mathrm{S}_{1}\right)$ are classified as of poor quality.

Afterwards, the average values of the chemical oxygen demand in the waters of the downstream sites $\left(\mathrm{S}_{2}\right.$ and $\left.\mathrm{S}_{3}\right)$ are $253.9 \mathrm{mg} \mathrm{\textrm {O } _ { 2 }} / 1$ and $175.2 \mathrm{mg} \mathrm{O} / 1$ respectively. For these sites, all the COD values obtained during the study period were very high. The results were then compared to the Moroccan quality grid (SEEE, 2007) and revealed the water's quality at the sites $\left(\mathrm{S}_{2}\right.$ and $\left.\mathrm{S}_{3}\right)$ to be classified as very poor.

Considering that the two sites are mainly supplied by the water from the discharge point, they are strongly impacted by all forms of contaminants emanating from this wastewater. As a

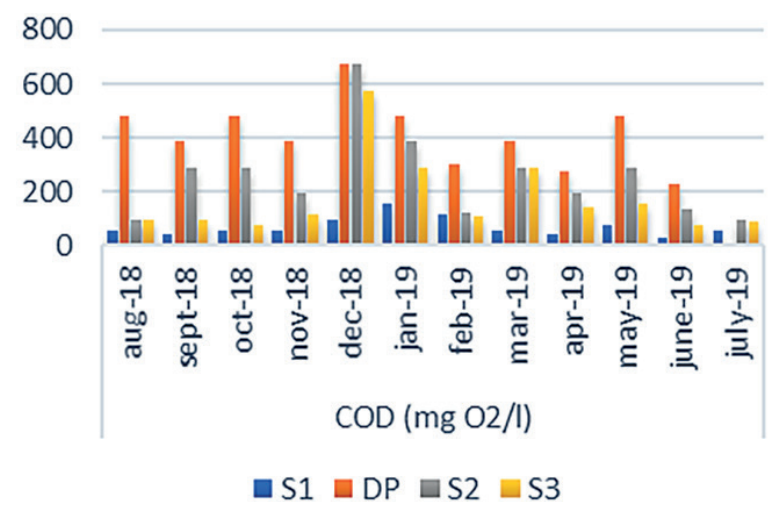

Figure 7. Spatio-temporal variation of COD

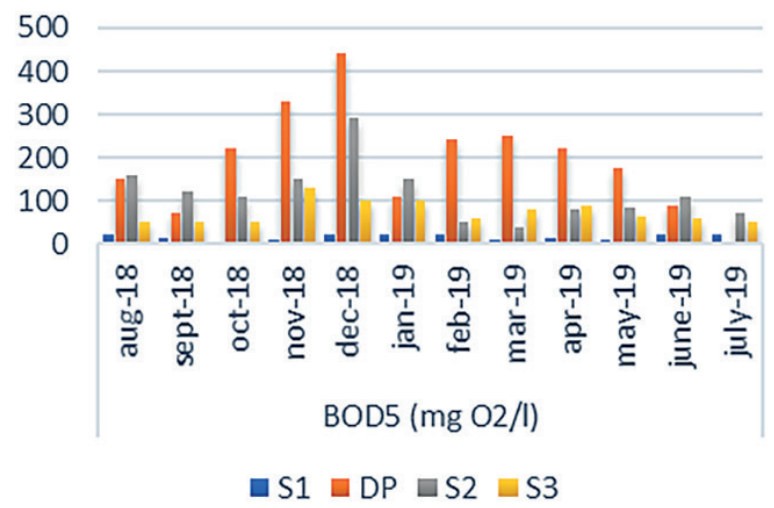

Figure 8. Spatio-temporal variation of $\mathrm{BOD}_{5}$ 
matter of fact, all COD values of the wastewater from the sewage are above the maximum Moroccan standard accepted value (MDCEau, 2014 b). The high values recorded for the wastewater might be related to the presence of a large amount of detergents and organic matter from domestic pollution, as well as oils and other contaminants from urban pollution in the waters.

On the basis of the results shown in Figure 8, the $\mathrm{BOD}_{5}$ values tend to increase moving from the upstream to the downstream of Oued Nfifikh. In fact, the BOD values fluctuate between $5 \mathrm{mg}$ $\mathrm{O}_{2} / 1$ and $20 \mathrm{mg} \mathrm{O}_{2} / 1$ in site $\left(\mathrm{S}_{1}\right)$ with an average value of $15 \mathrm{mg} \mathrm{O}_{2} / 1$. Consequently, the waters of this site are qualified as of medium to poor quality (SEEE, 2007). In turn, at the downstream sites $\left(\mathrm{S}_{2}\right.$ and $\left.\mathrm{S}_{3}\right)$, the BOD values vary between $50 \mathrm{mg}$ $\mathrm{O}_{2} / 1$ and $290 \mathrm{mg} \mathrm{O}_{2} / 1$ and the average value of the BOD recorded is around $95 \mathrm{mg} \mathrm{O} / 1$. These high values could be explained by the abundance of organic matter due to heavy discharge of the wastewater effluent coming from the site (DP) and to the increase of the organic load in a limited space. According to the Moroccan surface water quality grid, the waters studied in $\left(\mathrm{S}_{2}\right.$ and $\left.\mathrm{S}_{3}\right)$ are qualified as of very poor quality (SEEE, 2007).

At the discharge point, the BOD showed a minimum value of $70 \mathrm{mg} \mathrm{O}_{2} / 1$ and a maximum value of $440 \mathrm{mg} \mathrm{O}_{2} / 1$ and on average a value of $208 \mathrm{mg} \mathrm{O}_{2} / 1$. Thereby, the majority of BOD values registered during this study concerning the wastewater were found to be beyond the permissible limit (MDCEau, 2014 b). According to DeVillers et al. (2005), the higher the BOD, the higher the amount of organic matter present in a sample. As a matter of fact, the water coming from the site (DP) is mostly a domestic wastewater that is occasionally mixed with blackwater, and also the water that is highly contaminated by solid and dissolved matter brought by urban runoff discharges. To sum up, the high values of COD and $\mathrm{BOD}_{5}$ indicate a significant input of organic substances in Oued Nfifikh (downstream). Consequently, the discharge of the effluent coming from DP could constitute a danger for the receiving environment.

While taking into consideration what was deduced previously and according to Rodier et al. (2009), a characterization of the effluent by the determination of the relationship between the organic pollution parameters was performed. However, the $\mathrm{COD} / \mathrm{BOD}_{5}$ ratio of the wastewater varies from 1.1 to 5.4 and the average value of the $\mathrm{COD} / \mathrm{BOD}_{5}$ ratio is 2.4 (Table 2). Consequently,
Table 2. $\mathrm{COD} / \mathrm{BOD}_{5}$ ratio of the effluent (DP)

\begin{tabular}{|c|c|c|}
\hline Date & $\begin{array}{c}\text { COD/BOD } \\
\text { ratio }\end{array}$ & Biodegradability index \\
\hline Aug-18 & 3.2 & Moderately biodegradable \\
\hline Sept-18 & 5.4 & Hardly biodegradable \\
\hline Oct-18 & 2.1 & Highly biodegradable \\
\hline Nov-18 & 1.1 & Highly biodegradable \\
\hline Dec-18 & 1.5 & Highly biodegradable \\
\hline Jan-19 & 4.3 & Moderately biodegradable \\
\hline Fev-19 & 1.2 & Highly biodegradable \\
\hline Mar-19 & 1.5 & Highly biodegradable \\
\hline Apr-19 & 1.2 & Highly biodegradable \\
\hline Mai-19 & 2.7 & Highly biodegradable \\
\hline June-19 & 2.5 & Highly biodegradable \\
\hline July-19 & - & \\
\hline
\end{tabular}

- No data.

the wastewater evaluated in the present study can be regarded to have a domestic origin and is biodegradable, which could require a biological treatment before being discharged into the receiving environment, in a way to avoid the accumulation of organic load in a restrained space.

\section{Dissolved oxygen}

Throughout the study period, the evolution of dissolved oxygen (DO) amount in the water of Oued Nfifikh exhibits variations going from upstream to downstream (Fig. 9). The levels cover a wide range, with a minimum value of $0.4 \mathrm{mg} / 1$ and a maximum value of $14.2 \mathrm{mg} / \mathrm{l}$.

Starting by the upstream site $\left(\mathrm{S}_{1}\right)$, the results show that the oxygen concentrations increase during the wet period due to the decrease in temperature and vice versa. As it happens, Hébert and Légaré (2000) demonstrated that cold water contains more dissolved oxygen than hot water. This

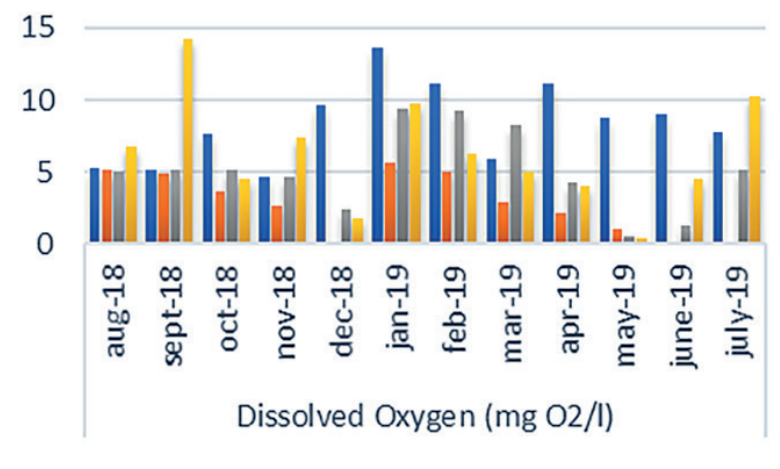

$\square \mathrm{S} 1 \mathrm{DP} \square \mathrm{S} 2 \square \mathrm{S} 3$

Figure 9. Spatio-temporal variation of dissolved oxygen 
remark is in agreement with other works carried out on different streams (Villeneuve et al. 2006; Makhoukh et al. 2011). Therefore, the values obtained at the upstream site follow a fairly common evolution of the oxygen content in surface waters. With an average value of $8.3 \mathrm{mg} / \mathrm{l}$ and according to the Moroccan surface water quality grid, the water evaluated at $\left(\mathrm{S}_{1}\right)$ is qualified as excellent (SEEE, 2007).

There is a significant drop of the DO content in December at all downstream sites, including the wastewater discharge, which coincides with the increase of the BOD in the same month. In fact, the higher the BOD, the more important the oxygen is depleted in the water. Consequently, the oxygen depletion could be followed by anaerobic conditions, which would result in reduced diversity and distribution of aquatic fauna. Further, the presence of organic matter will promote the accumulation of toxic compounds in water bodies (DeVillers et al., 2005; SIAQUEBA, 2018). The average DO concentration values are respectively $5 \mathrm{mg} / 1$ and 6.2 $\mathrm{mg} / \mathrm{l}$ for the sites $\left(\mathrm{S}_{2}\right.$ and $\mathrm{S}_{3}$ ), thus qualifying these water quality statuses as good (SEEE, 2007).

The lowest values of DO content observed for the wastewater with an average value of $3 \mathrm{mg} / \mathrm{l}$. These results are in agreement with those found by Popa et al. (2012) for urban wastewater in Romania and lightly similar to those found by Azami et al. (2015) for the wastewater from Azilal city. This deficit in DO content probably related to the high organic loads in the wastewater. As a matter of fact, dissolved oxygen concentration is a function of the rate of oxygen depletion in an environment by the activity of microbial flora and the decomposition of organic matter present in the water (Hébért and Légaré 2000; DeVillers et al., 2005). Therefore, low DO concentrations can cause serious damage to the receiving environment. However, no standards are given by the Moroccan law for dissolved oxygen in wastewater.

\section{Nutrients}

Elements such as nitrogen $(\mathrm{N})$ and phosphorus $(\mathrm{P})$ are mineral elements considered essential to plant growth and development. They are generally used in agriculture as fertilizers. These substances are normally generated by the mineralization of organic matter (DeVillers et al., 2005; Rodier et al., 2009). However, if they are present in too large quantities as a result of wastewater discharges in a precarious manner, they promote the proliferation of photosynthetic algae and micro-organisms that reduce the penetration of light into deep water layers (DeVillers et al., 2005; Rodier et al., 2009). The decomposition of dead algae induces oxygen consumption and when water is too low in oxygenation, anaerobic conditions may also result in an accumulation of ammonia and nitrite compounds likely to poison fauna and flora (DeVillers et al., 2005; Rodier et al., 2009).

The forms evaluated in this study are the ammonium ions (Fig. 10) and total phosphorus (Fig. 11). However, measurement of different forms of nutrient variations is strongly needed in order to maintain the water quality of Oued Nfifikh.

\section{Ammonium ions $\left(\mathrm{NH}_{4}^{+}\right)$}

Figure 10 shows that the $\mathrm{NH}_{4}^{+}$concentrations along the watercourse vary between $0 \mathrm{mg} / 1$ and $41.53 \mathrm{mg} / \mathrm{l}$. For this component, concentrations are higher at the wastewater discharge site (DP), where the average concentration value recorded is about $14.04 \mathrm{mg} / \mathrm{l}$, undoubtedly affecting the ammonium ion concentrations at the downstream sites, where the average concentration values are $11.78 \mathrm{mg} / \mathrm{l}$ and $7.39 \mathrm{mg} / \mathrm{l}$ for $\left(\mathrm{S}_{2}\right.$ and $\mathrm{S}_{3}$ ), respectively.

The natural sources of ammoniacal nitrogen are diverse, the gas exchanges with the atmosphere, as well as, the biochemical transformations of the organic and inorganic nitrogenous substances in the physical matrices of the streams, along with its excretion by the biota could be mentioned among other examples (Rodier et al., 2009; SIAQUEBA, 2018). However, the main source of this element in watercourses is anthropogenic. Domestic effluents loaded with organic matter and urea represent the most important source. It may also come from urban runoff,

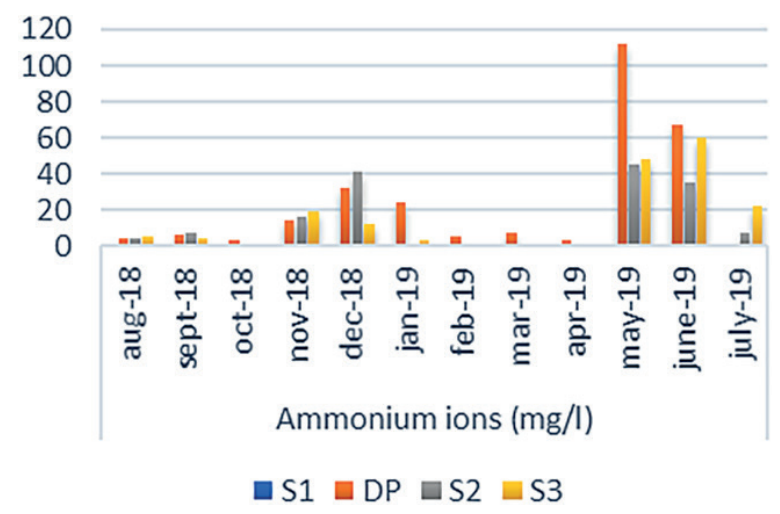

Figure 10. Spatio-temporal variation of ammonium ions 
agriculture and industrial activities (Rodier et al., 2009; Popa et al., 2012; SIAQUEBA, 2018).

Coinciding with the releases of masses of domestic wastewater combined with black water containing urine and faeces, noticeable increases in the $\mathrm{NH}_{4}^{+}$concentrations were observed from November, with high peaks in December at downstream sites, including site (DP). Thus, supporting the findings of (Rodier et al., 2009; Popa et al., 2012; SIAQUEBA, 2018). Furthermore, it also demonstrates that the ammonium is the main chemical indicator of direct organic pollution.

The ammonium values recorded in January at the downstream sites are much lower than those found during the months when the releases of masses of grey and black water were observed; this decrease is probably due to dilution by rainwater. The authors Derwich et al. (2008), Makhoukh et al. (2011) came to the same conclusion by studying other Moroccan rivers.

To summarize, the ammonium contents are unsatisfactory in the waters downstream of the Oued $N f i k h k h$, the overall quality status of these sites is poor to very poor (SEEE, 2007). In contrast, for the upstream site $\left(\mathrm{S}_{1}\right)$, its overall quality status is excellent (SEEE, 2007). Ammoniacal nitrogen is a toxic by-product for aquatic fauna (SIAQUEBA, 2018). However, no discharge limit value or a Moroccan standard exists in this respect.

\section{Total phosphorus}

The concentrations of total phosphorus in the waters analyzed vary between $0.07 \mathrm{mg} / \mathrm{l}$ recorded in $\left(\mathrm{S}_{1}\right)$ and $15 \mathrm{mg} / 1$ recorded in (DP) (Fig. 11).

Generally, the presence of this element in natural waters comes from the leaching of certain minerals and the decomposition of organic matter, along with wastewater discharge from anthropogenic

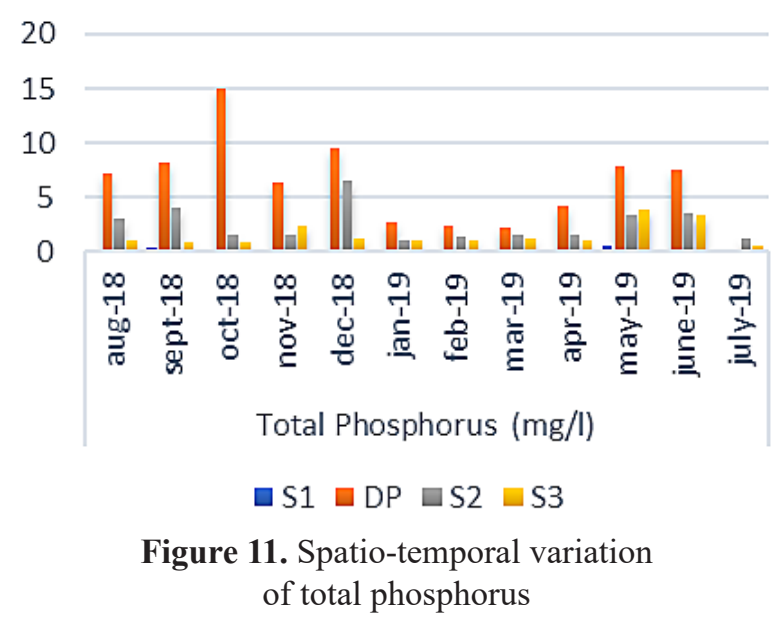

activities, as well as the use of detergents and drainage of fertilized agricultural lands (Hébert and Légaré, 2000; CEAEQ, 2011; SIAQUEBA, 2018).

The average concentrations of total phosphorus follow an increasing gradient from upstream to downstream. The same results were found for the wastewaters discharged at the level of Oued Hassar (Fouad et al., 2014; Nahli et al., 2015). The concentrations injected by the discharge from the site (DP) remain constant or even tend to increase. It is perhaps the dilution by rainwater which made it possible to lower these levels (January 2019).

Phosphorus is not toxic to humans or wildlife. However, in order to slow the proliferation of algae in the environment (eutrophication) its content must be controlled (CEAEQ, 2011). By reference to the water resources quality grid, the average total phosphorus content classifies the water from the site upstream $\left(\mathrm{S}_{1}=0.16 \mathrm{mg} / \mathrm{l}\right)$ of the Oued Nfifikh in the good quality range (SEEE, 2007). In turn, the average total phosphorus contents in the water of the sites downstream of the watercourse $\left(\mathrm{S}_{2}=2.97 \mathrm{mg} / \mathrm{l} ; \mathrm{S}_{3}=1.22 \mathrm{mg} / \mathrm{l}\right)$, classify the water as of poor quality (SEEE, 2007). However, no standards are given by the Moroccan law for total phosphorus in domestic wastewater.

\section{CONCLUSIONS}

The aim of this work was to assess the physicochemical quality of the Oued Nfifikh and to determine the impacts of urban effluents discharged directly into the watercourse without prior treatment. As limits encountered in this characterization, the absence of Moroccan standards and limit values for some physicochemical parameters, whether for surface water or wastewater discharges, were cited. On the basis of the available water assessment standards, the urban wastewater effluent does not exceed the discharges limits concerning temperature, $\mathrm{pH}$, electrical conductivity, turbidity and TSS. When it comes to the physicochemical parameters of organic pollution, such as, the COD and the $\mathrm{BOD}_{5}$, the results obtained are above the standards. Consequently, the discharge of this raw sewage into the downstream part of Oued Nfifikh can have harmful impacts on the ecological status of this ecosystem, as well as on the riparian population.

The variations in surface water flow have a significant impact on water quality. As a matter of fact, when flow rates decrease while discharges remain constant, pollutants become concentrated, and the 
water quality decreases. Furthermore, during thunderstorms, the flow rates of the stream increase significantly, thus altering the quality. The high-water pressure evacuates the deposits of sludge and dirt accumulated in the pipes. Consequently, the runoff water loaded with the pollutants from leaching land and the road network affects the transparency and the overall quality of the receiving environment. Thus, and according to the surface water quality grid, the water quality of the downstream part of Oued Nfifikh is qualified as poor to very poor, contrary to the upstream part where the average assessed quality is good to excellent.

In the light of these results, it can be recommended that the concerned authorities set up urban wastewater treatment plants and connect these discharges to the station in order to limit or stop the impact of these effluents on the Oued Nfifikh.

\section{Acknowledgments}

We would like to thank Mr. Brahim Hadad (Professor at the CRMEF of Casablanca Settat-Morocco) and Miss Fatima Ezzahra Kismi (Teacher of English literature at Laaounate/Sidi Bennour-Morocco) for kindly proofreading this article. May they find in this article the pledge of our respect and gratitude.

\section{REFERENCES}

1. Agence du Bassin Hydraulique du Bouregreg et de la Chaouia. 2015. Etat de la qualité des ressources en eau dans la zone d'action de l'Agence du Bassin Hydraulique du Bouregreg et de la Chaouia en 2014, 1-30.

2. Agence du Bassin Hydraulique du Bouregreg et de la Chaouia. 2011. Réseau de mesure des eaux souterraines et superficielles de l'Agence du Bassin Hydraulique du Bouregreg et de la Chaouia. Benslimane Août, 1-12.

3. Agence de l'Environnement et de la Maitrise de l'Energie. 2013. Guide méthodologique d'évaluation des émissions de gaz à effet de serre des services de l'eau et de l'assainissement. Guide sectoriel. ASTEE Bilan GES des services d'eau et d'assainissement. 3éme édition, Mai, 1-46.

4. Akil M. 1990. Les dépôts quaternaires littoraux entre Casablanca et Cap Beddouza (Méséta côtière marocaine) - Etude géomorphologique et sédimentologique. D.E.S., troisième cycle de géologie. Faculté des Sciences de Rabat, université Mohammed, 137.

5. Azami Idrissi Y., Alenad A., Aboubaker S., Daifi H., Elkharrim K., Belghyti D. 2015. Caractérisation physico-chimique des eaux usées de la ville
d'Azilal-Maroc. International Journal of Innovation and Applied Studies, 11(3), 556-566.

6. Bzioui M. 2004. Rapport national 2004 sur les ressources en eau au Maroc. Novembre. UN Water Africa, 1-94.

7. Centre d'Expertise en Analyse Environnementale du Québec. 2011. Détermination du phosphore total dans les effluents : digestion à l'autoclave avec persulfate, méthode colorimétrique automatisée, MA. 315- P2.0, Ministère du Développement durable, de l'Environnement et des Parcs, 11.

8. Communal monography (Monographie communale). 2010. Commune rurale de BniYakhlef. Préfecture de Mohammedia. Hydraumet, 1-16.

9. Derwich E., Beziane Z., Benaabidate L., Belghyti D. 2008. Evaluation de la qualité des eaux de surface des Oueds Fes et Sebou utilisées en agriculture maraichère au Maroc. Larhyss Journal, 7, 59-77.

10. De Villers J., Squilbin M., Yourassowsky C. 2005. Qualité physico-chimique et chimique des eaux de surface : Cadre Général. Fiche technique. Institut Bruxellois pour la Gestion de l'Environnement (IBGE). Observatoire des données de l'environnement, Novembre, 1-16.

11. El Haji M., Boutaleb S., Laamarti R., Laarej L. 2012. Qualité des eaux de surface et souterraine de la région de Taza (Maroc): bilan et situation des eaux. Afrique Science, 8(1), 67-78.

12. Farki K., Zahour G., Baroudi Z., Alikouss S., Zerhouni Y., El Hadi H., Darhnani M. 2016. Mines et carrières triasico-liasiques de la région de Mohammedia : inventaire, valorisation et étude d'impact environnemental. International Journal of Innovation and Scientific Research, 20(2), 306-326.

13. Farki K., Zahour G., El Hadi H., Alikouss S., Zerhouni Y. 2014. Les tholéiites fini triasiques de Mohammedia (meseta côtière, Maroc) : Témoins d'un volcanisme de Rift intracontinental avorté. European Scientific Journal, 10(20).

14. Farki K., Zahour G., Zerhouni Y., Hamid W. 2012. Contribution à la compréhension de l'évolution sédimentaire et tectono-volcanique de la série Triasico-Liasique de l'Oued Nfifikh (meseta côtière, Maroc). Ann. Soc. Géol. Du Nord. T., 19(2), 1-12.

15. Fouad S., Hajjami K., Cohen N., Chlaida M. 2014. Qualité physico-chimique et contamination métalliques des eaux de l'Oued Hassar : impacts des eaux usées de la localité de Médiouna (péri-urbain de Casablanca, Maroc). Afrique Science, 10, 91-102.

16. Makhoukh M., Sbaa M., Berrahou A., Van Clooster M. 2011. Contribution à l'étude physico-chimique des eaux superficielles de l'Oued Moulouya (Maroc Oriental). Larhyss Journal, 9, Décembre, 149-169.

17. Gartet A., Gartet J., Garcia C. 2001. Hydrochimie des eaux, dissolution spécifique et salinité des cours 
d'eau dans le bassin de l'Oued Lebène (Périf Central, Maroc septentrional). Papeles de Geograffa. BIBLID, 143-161.

18. General monography. 2015. La région de Casablanca-Settat. Royaume du Maroc, Ministère de l'Intérieur Direction Générale des Collectivités Locales, 1-47.

19. Hayzoun H., Ouammou A., Saidi O., Khalil F. 2014. Assessment of the Bacteriological and Chemical Quality of the Sebou River, Morocco. Journal of Materials and Environmental Science, 5, 2438-2443.

20. Hebert S., et Legare S. 2000. Suivi de la qualité des rivières et petits cours d'eau. Québec. Direction du suivi de l'état de l'environnement, ministère de l'environnement, envirodoq $\mathrm{n}^{\circ}$ ENV-2001-0141, rapport $n^{\circ} \mathrm{QE}-123,24$ p. et 3 annexes.

21. Iounes N., Kabriti M., El Amrani S. 2016. Caractérisation physico-chimique et analyse biologique des eaux de surface de l'Oued Daliya, Maroc. Afrique Science.

22. Lakhili F., Benabdelhadi M., Bouderka H., Lahrach H., Lahrach A. 2015. Etude de la qualité physicochimique et de la contamination métallique des eaux de surface du bassin versant de Beht (Maroc). European Scientific Journal, 11, 132-147.

23. Lechevallier M.W., Evans J.M., Selder R.J. 1981. Effect of turbidity on chlorination efficiency in drinking water. Applied and Environmental Microbiology, 42(1), 159-167.

24. MDCEau (Ministère Délégué auprès du Ministère de l'Energie, des Mines, de l'Eau et de l'Environnement, chargé de l'Eau) (2014) a. Etat de la qualité des ressources en eau au Maroc, année 2009-2012. Rapport. Direction de la recherche et de la planification de l'eau. Division qualité de l'eau, Service surveillance de la qualité de l'eau. Juin. Rabat.

25. MDCEau (Ministère Délégué auprès du Ministère de l'Energie, des Mines, de l'Eau et de l'Environnement, chargé de l'Eau) (2014) b. Préservation de la qualité des ressources en eau et lutte contre la pollution (valeurs limites de rejets à respecter par les déversements (Normes de pollution)). Rapport. Direction de la recherche et de la planification de l'eau. Division qualité de l'eau, Service surveillance de la qualité de l'eau. Juin. Rabat.

26. MDCEau (Ministère Délégué auprès du Ministère de l'Energie, des Mines, de l'Eau et de l'Environnement, chargé de l'Eau) (2009). Etat de la qualité des ressources en eau au Maroc, année 2007-2008. Rapport. Département de 1'Eau. Direction de la recherche et de la planification de l'eau. Octobre. Rabat.

27. Mounjid J., Fadlaoui S., Belhouari A. 2014. Contribution à l'évaluation de la qualité physico-chimique du cours d'eau Merzeg (péri-urbain de Casablanca, Maroc). Larhyss Journal, 18(Juin), 31-51.

28. Nahli A., Hebabaze S., Belmatrik S., Chlaida M. 2015. Diagnostic préliminaire de la qualité physico-chimique des eaux de l'Oued Hassar après l'installation de la station d'épuration de Médiouna (Casablanca, Maroc). International Journal of Innovation and Applied Studies, 13(4), 965-978.

29. N'diaye A.D., Thiam O., Ould Kankou M., Ibno Namr K. 2013. Turbidité et matières en suspension dans l'eau : Application à l'évaluation des métaux contenus dans l'eau de la rive droite du fleuve Sénégal. Larhyss Journal, 14, 93-105.

30. NF EN ISO 5667-1 (Mars 2007). Qualité de l'eau - Echantillonnage -Partie 1 : lignes directrices pour la conception des programmes et des techniques d'échantillonnage (Indice de classement: T90-511-1).

31. Oubraim S. 2002. Qualité physico-chimique et biologique des cours d'eau du réseau hydrographique de la Meseta occidentale marocaine : Cas de l'Oued Mellah. Thèse de Doctorat: Sciences de l'environnement. Faculté des sciences Ben M'Sik - Université Hassan II.

32. Popa P., Timofti M., Voiculescu M., Dragan S., Trif C., Georgescu L.P. 2012. Chemical characteristics of wastewater in an urban agglomeration in Romania. The Scientific World Journal, 1-10.

33. Réfea (REseau Francophone sur 1'Eau et l'Assainissement). 2001. Fiche d'analyse physicochimique [en ligne]. Disponible sur

34. https://www.oieau.org/ReFEA/fiches/AnalyseEau/Physico_chimie_PresGen.htm [Consulté le 13 Aout 2018].

35. Reggam A., Bouchelaghem H., Houhamdi M. 2015. Qualité physico-chimique des eaux de l'Oued Seybouse (Nord-Est de l'Algérie) : Caractérisation et analyse en composantes principales. J. Mater. Environ. Sci. (JMES), 6(5), 1417-1425.

36. Rodier J., Legube B., Merlet N., Coll. 2009. L'analyse de l'eau. 9éme Edition, Dunod, Paris, 1579.

37. SEEE(Secrétariatd'Etatdel'Eauetdel'Environnement) (2007). Normes de qualité : Eaux de surfaces. Grille de qualité. Secrétariat d'Etat auprès du Ministère de l'Energie des Mines de l'Eau et de l'Environnement, chargé de l'Eau et de l'Environnement. Rabat.

38. SIAQUEBA (Syndicat Intercommunal de l'Amélioration de la Qualité des Eaux de la Brague et de ses Affluents) (2018). Suivi de la qualité des eaux de la Brague et de ses affluents : campagnes 2017. Département des Alpes-Maritimes. Janvier, 1-54.

39. Tazi O., Loutfi M., Casanovas F.P., Fahde A. 2004. Impact du climat sur le réseau hydrographique Nfefikh (Meseta atlantique du Maroc), 4(14), 361-365.

40. Villeneuve V., Legare S., Painchaud J., Vincent W. 2006. Dynamique et modélisation de l'oxygène dissous en rivière. Revue des Sciences de l'Eau, 19(4), 259-274.

41. Yapo T.W., Mambo V., Yapo O.B., Seka A., Houenou P.V. 2012. Physico chemical evaluation of wastewater from the main sewer in Abidjan city. Journal of Ecology and the Natural Environment, 4(1). 